\title{
Comments on the Names of the Islands of the Galaipagos
}

There is a problem in the application of names to the various islands of the Galápagos Archipelago due to the fact that there are two sets of designations, one in English and the other in Spanish. The larger islands have both Spanish and English names, whereas many of the smaller islands bear only English names. Furthermore, several islands have two or more names in English and/or Spanish. Although the official Spanish names for Charles and James islands are Santa María and San Salvador, respectively, local residents prefer to call them Floreana and Santiago, respectively, and some of them may be unaware of the "official" Spanish names.

A recent study (J. R. Slevin, Occas. Papers Calif. Acad. Sci., 25, 1959: 1-150) has shown that the first names to be applied to individual islands of the Galápagos were given in English by Cowley in 1684, with the following readily identifiable: Culpepper, Wenman, Abingdon, Bindloe, Narborough, Albemarle, James, Charles, Brattle, and Crossman. One of the earliest maps bearing island names in Spanish appeared in 1744, but only Isabel (= Isabela = Albemarle) can be positively identified by comparing it with a modern map. British Admiralty surveys, beginning in 1835 with those by Captain Fitz-Roy of H.M.S. Beagle, form the basis for all modern maps of the Galápagos.

In 1892 the Galápagos was renamed Archipiélago de Colón by the government of the Republic of Ecuador, to which country it belongs. Official Spanish names were assigned all major islands, but many islets were left unnamed and have only their original English designations. Assuredly, the islands as a group will continue to be known popularly, in Ecuador and abroad, as "Galápagos" (in reference to the giant land turtles which populate many of the islands), and men of letters will perpetuate the more romantic name, "Las Encantadas" (in reference to the plight of thirst-tormented sailors of past centuries, becalmed for days in sight of these bewitched isles).

In view of the somewhat confusing nomenclatural picture, it was decided that throughout this volume English names would be used for all the islands and geographic features. In support of this position we need only remind the reader that English names have an historical priority and that in the past most of the scientific collecting localities have been identified by English designations.

A partial synonomy of English and Spanish names appears below.

\begin{tabular}{ll} 
English Names & Official Ecuadorian Names \\
Abingdon & Pinta, Geraldino \\
Albemarle & Isabela, Santa Gertrudis \\
Barrington & Santa Fé \\
Bartholomew & Bartholomé \\
Bindloe & Marchena, Torres \\
Champion & - \\
Charles & Santa Marí, Floreana \\
Chatham, Dassigney & San Cristóbal, Grande \\
Culpepper & Darwin, Guerra \\
Daphne Major & - \\
Daphne Minor & - \\
Duncan, Dean & Pinzón \\
Eden & - \\
Gardner-near- & - \\
\multicolumn{1}{c}{ Charles } & \\
Gardner-near-Hood & Española \\
Hood & Santa Cruz, Bolivia, Cha- \\
Indefatigable, Nor- & vez, San Clemente, Val- \\
\multicolumn{1}{|c}{ folk, Porter } & dez \\
James, York & San Salvador, Santiago, \\
Jervis & Gil, Olmedo \\
Narborough & Rábida \\
North Seymour & Fernandina, Plata \\
- Seymour \\
South Seymour & Plaza \\
Tower, Ewres & Genovesa \\
Wenman & Wolf, Gasna, Nuñez \\
&
\end{tabular}

a Preferred English names in boldface type; other names in lightface.

b Official names in boldface type, and locally preferred names, when different from official names, in italics; other names in lightface. 
